\title{
PROFITABILITAS DAN RETURN SAHAM: PERAN MODERASI ARUS KAS OPERASI DAN UKURAN PERUSAHAAN
}

\author{
Murni Prasetyaningrum \\ Magister Akuntansi Fakultas Ekonomi,Universitas Sebelas Maret \\ prasetyo_myp@yahoo.com
}

\begin{abstract}
This studyaims todetermine the effect ofprofitabilityon stock returnswithoperatingcash flowandfirm sizeas a moderating variableofcompanies listedon theIndonesia Stock Exchangein 2006-2008. The population inthis study is allcompanies listedon theIndonesia Stock Exchange. Sample is takenby usingpurposivesamplingmethod. The hypothesisis tested usingregressionwithvariablemoderation. Results of this studyshowthatprofitabilityhas a positive effecton stock returns, operatingcash flowdoes not significantly moderate the relationshipbetweenprofitabilityandstock returns, firm size does notmoderate the relationshipbetweenprofitabilityandstock returns.
\end{abstract}

Keyword: Profitability, Stock Returns, Operating Cash Flow, Size.

\section{PENDAHULUAN}

Salah satu fungsi pasar modal adalah sebagai sarana untuk memobilisasi dana yang bersumber dari masyarakat ke berbagai sektor yang melaksanakan investasi (Linda dan Syam 2005). Syarat utama yang diinginkan oleh para investor untuk bersedia menyalurkan dananya melalui pasar modal adalah perasaan aman akan investasi dan tingkat return yang akan diperoleh dari investasi tersebut. Perasaan aman ini diperoleh karena para investor memperoleh informasi yang jelas, wajardan tepat waktu sebagai dasar dalam pengambilan keputusan investasinya. Return memungkinkan investor untuk membandingkan keuntungan aktual ataupun keuntungan yang diharapkan yang disediakan oleh berbagai investasi pada tingkat pengembalian yang diinginkan.

Pasar modal pada dasarnya bertujuan untuk menjembatani aliran dana dari pihak yang memiliki dana (investor) dengan pihak yang membutuhkan dana (perusahaan) dan memberikan peluang dan kesempatan bagi pemilik dana untuk memperoleh return sesuai dengan karakteristik investasi yang dipilih. Syarat utama yang diinginkan oleh para investor untuk bersedia menyalurkan dananya melalui pasar modal adalah perasaan aman akan investasi dan tingkat return yang akan 
diperoleh dari investasi tersebut. Return memiliki peran yang sangat signifikan dalam menentukan nilai dari suatu investasi (Daniati dan Suhairi2006).

Prasetyo (2008) menyatakan bahwa informasi akuntansi dalam bentuk laporan keuangan banyak memberikan manfaat bagi para pengguna apabila laporan tersebut dianalisis lebih lanjut sebelum dimanfaatkan sebagai alat bantu pembuat keputusan bisnis pada saat aktivitas jual beli saham di bursa efek. Laporan perusahaan memberikan informasi tentang kinerja, aliran kas perusahaan dan informasi lain yang berkaitan dengan laporan keuangan. Informasi tersebut setidaknya harus memungkinkan mereka untuk melakukan proses penilaian (valuation) saham. Suatu laporan keuangan dikatakan memiliki kandungan informasi bila publikasi dari laporan tersebut menyebabkan bergeraknya reaksi pasar. Reaksi pasar ini ditunjukkan dengan adanya perubahan dari harga sekuritas yang bersangkutan yang lazimnya diukur dengan menggunakan return saham sebagai nilai perubahannya.

Brevik dan D'addona (2010) menyebutkan bahwa publikasi laporan keuangan merupakan sebuah sinyal yang menggambarkan kondisi ekonomi perusahaan. Kualitas informasi yang baik akan membuat investor mampu untuk membuat peramalan yang lebih tepat sehingga dapat menurunkan risiko investasi. Bo (2009) menyatakan bahwa pasar modal yang efektif, keberadaan informasi akuntansi akan berdampak terhadap harga saham perusahaaan. Semakin baik informasi akuntansi, akan semakin membantu investor untuk menentukan dengan tepat harga saham perusahaan.

Informasi akuntansi yang berlebih adalah sesuatu yang berguna bagi investor untuk menentukan harga saham. Watson dan Wells (2005) menguji pengaruh laba dan arus kas operasi terhadap kinerja perusahaan yang diukur dengan return saham perusahaan. Penelitian tentang pengaruh laba dan arus kas sangat penting dilakukan karena tingginya perhatian dari para partisipan pasar modal terhadap laba dan arus kas. Para peneliti, pembuat standar, analis pasar dan para komunitas bisnis sangat berfokus terhadap informasi laba dan arus kas terutama untuk menentukan kinerja saham perusahaan.

Para peneliti tersebut menyatakan bahwa data arus kas mempunyai manfaat dalam beberapa konteks keputusan, seperti: (1) memprediksi kesulitan keuangan, (2) menilai risiko, ukurandan waktu keputusan pinjaman, (3) memprediksi peringkat (rating) kredit, (4) menilai perusahaan dan (5) memberikan informasi tambahan pada pasar modal. Meythi (2006) berpendapat beberapa literatur menganggap bahwa data arus kas merupakan indikator keuangan yang lebih baik dibandingkan dengan akuntansi karena laporan arus kas relatif lebih mudah diinterpretasikan dan relatif lebih sulit untuk dimanipulasi.

Daniati dan Suhairi (2006) menyebutkan bahwa parameter kinerja perusahaan yang mendapat perhatian utama dari investor dan kreditor dari laporan keuangan ini adalah laba dan arus kas. Pada saat dihadapkan pada dua ukuran kinerja akuntansi keuangan tersebut, investor dan kreditor harus yakin bahwa ukuran kinerja yang menjadi fokus perhatian mereka adalah ukuran kinerja yang mampu menggambarkan 
kondisi ekonomi perusahaan serta prospek pertumbuhan dimasa depan dengan lebih baik. Penelitian ini menyebutkan bahwa selain laba dan arus kas ukuran perusahaan juga merupakan salah satu parameter yang dapat berpengaruh terhadap return saham. Berdasarkan hal tersebut penelitian ini menguji peran arus kas operasi dan ukuran perusahaan sebagai variabel moderasi dalam hubungan antara profitabilitas dan return saham.

\section{TINJAUAN TEORITIS DAN PENGEMBANGAN HIPOTESIS}

\section{Return Saham}

Saham adalah salah satu bentuk efek yang diperdagangkan dalam pasar modal. Saham merupakan surat berharga sebagai tanda pemilikan atas perusahaan penerbitnya. Saham juga berarti sebagai tanda penyertaan atau pemilikan seorang atau badan dalam suatu perusahaan terbuka. Saham menarik bagi investor karena berbagai alasan. Bagi beberapa investor, membeli saham merupakan cara untuk mendapatkan kekayaan besar (capital gain) yang relatif cepat. Sementara, bagi investor yang lain, saham memberikan penghasilan yang berupa dividen (Primandoko 2005).

Munte (2009) menjelaskan bahwa harapan dari seorang investor akan investasinya adalah memperoleh tingkat return sebesar-besarnya pada tingkat risiko tertentu. Return adalah indikator peningkatan kemakmuran bagi pemegang saham. Tujuan didirikannya perusahaan adalah untuk meningkatkan nilai pemegang saham perusahaan. Semakin besar return saham akan semakin tinggi pula nilai perusahaan yang artinya akan semakin tinggi pula kesejahteraan dari para pemegang saham perusahaan.

Return merupakan pengembalian suatu hasil yang diperoleh dari suatu investasi. Return sahamdibagi menjadi dua macam yaitu return realisasi (realized return) dan return ekspektasi (expected return). Return realisasi merupakan return yang telah terjadi dan dihitung berdasarkan data historis. Return realisasi penting karena digunakan sebagai salah satu pengukur kinerja dari perusahaan. Return historis juga berguna sebagai dasar penentuan return ekspektasi dimasa yang akan datang. Return ekspektasi merupakan return yang diharapkan akan diperoleh informasi ini juga membantu manajer dalam mengawasi efisiensi modal kerja yang digunakan dalam perusahaan, informasi ini juga dibutuhkan oleh kreditor jangka panjang dan pemegang saham yang ingin mengetahui prospek dari pembayaran dividen dan pembayaran bunga dimasa yang akan datang (Hartono 2003).

Prasetyo (2003) menyebutkan bahwa pasar modal merupakan bagian dari pasar keuangan, yang menjalankan fungsi ekonomi dan keuangan. Fungsi ekonomi yang dijalankan pasar modal melibatkan dua pihak yaitu pihak yang kelebihan dana dan pihak yang membutuhkan dana. Fungsi keuangan ditunjukkan dengan kemungkinan memperoleh imbalan (return) bagi pemilik dana, sesuai dengan karakteristik yang dipilih. Bagi pihak yang membutuhkan dana, tersedianya dana dari 
pihak luar memungkinkan perusahaan untuk melakukan investasi tanpa harus menunggu tersedianya dana dari hasil operasi perusahaan.

Lestari (2005) berpendapat pada awal mula penulisan literatur pasar efisien, pasar modal dikatakan efisien bila perubahan harga saham tidak dapat diprediksi atau random. Dengan kata lain, harga saham mengikuti model random walk, sehingga tidak mengherankan bila model random walk di sini hampir dipersepsikan identik dengan hipotesis pasar efisien. Harga saham yang bergerak secara random tersebut merupakan konsekuensi dari reaksi para investor yang rasional yang saling berkompetisi untuk mendapatkan informasi yang baru sebelum investor lain menemukan informasi tersebut untuk pengambilan keputusan membeli atau menjual saham di pasar modal.

Auliyah dan Hamzah (2006) menyatakan saham merupakan salah satu sekuritas diantara sekuritas-sekuritas lainnya yang mempunyai tingkat risiko yang tinggi. Risiko tinggi tercermin dari ketidakpastian return yang akan diterima oleh investor di masa datang. Hal ini sejalan dengan definisi investasi bahwa investasi merupakan komitmen dana dengan jumlah yang pasti untuk mendapatkan return yang tidak pasti di masa depan. Dengan demikian, ada dua aspek yang melekat dalam suatu investasi, yaitu return yang diharapkan dan risiko tidak tercapainya return yang diharapkan. Return dan risiko secara teoritis pada berbagai sekuritas mempunyai hubungan yang positif. Semakin besar return yang diharapkan diterima, maka semakin besar risiko yang akan diperoleh, begitu pula sebaliknya.

\section{Hubungan Profitabilitas denganReturn Saham}

Seiring dengan perkembangan jaman sekarang ini, dunia usaha menuntut adanya informasi yang bisa digunakan sebagai dasar pengambilan keputusan bisnis. Untuk mendapatkan informasi yang berguna bagi para pelaku bisnis tersebut, maka akuntansi ikut berperan dalam menyediakan informasi yang diperlukan. Laporan keuangan adalah salah satu informasi penting dan dapat dipercaya oleh pihak internal maupun eksternal perusahaan, karena laporan keuangan adalah informasi mengenai perkembangan perusahaan untuk periode tertentu. Laporan keuangan yang dibuat oleh perusahaan disajikan sebagai informasi yang menyangkut posisi keuangan perusahaan, laporan kinerja, perubahan posisi keuangan dan laporan aliran kas yang bermanfaat bagi pemakainya khususnya investor maupun kreditor dalam pengambilan keputusan (Juanita 2008).

Brevik dan D'addona (2010) menyebutkan bahwa kualitas informasi yang disampaikan dalam laporan keuangan perusahaan akan berpengaruh terhadap return saham. Wijayanti (2006) mengungkapkan bahwa informasi tentang laba (earnings) mempunyai peran sangat penting bagi pihak yang berkepentingan terhadap suatu perusahaan. Pihak internal dan eksternal perusahaan sering menggunakan laba sebagai dasar pengambilan keputusan seperti pemberian kompensasi dan pembagian bonus kepada manajer, pengukur prestasi atau kinerja manajemen dan dasar penentuan besarnya pengenaan pajak. 
Bagnoli et al. (2010) menyatakan bahwa pasar saham akan bereaksi terhadap informasi yang diberikan perusahaan terutama berkaitan dengan aspek laba perusahaan. Perubahan harga saham yang memengaruhireturn menunjukkan preferensi pasar akan saham mana yang profitabel atau tidak. Para analisis pasar akan melakukan berbagai analisis termasuk terhadap laba perusahaan sebelum memberikan rekomendasi terhadap pembelian saham. Apabila dua jenis sama-sama profitable namun kemudian satu saham lebih dipilih jika dibandingkan dengan saham lain, tentunya ada faktor lain diduga memengaruhi.

Perubahan laba tahunan berkorelasi dengan return saham residual, menjadi awal banyak penelitian yang secara konsisten menemukan bukti hubungan tentang relevansi dan ketepatwaktuan (timeliness) laba akuntansi. Hasil penelitian tersebut menunjukkan adanya hubungan antara laba kejutan dengan return residual yang secara statistik signifikan.

Linda dan Syam (2005) menunjukkan adanya hubungan positif antara laba tahunan dan tingkat keuntungan abnormal, artinya jika laba mengalami kenaikan maka rata-rata tingkat keuntungan abnormal juga akan meningkat dan peningkatan itu terjadi sepanjang tahun, sebaliknya jika perubahan laba tersebut berupa penurunan maka tingkat keuntungan abnormal juga akan menurun terus sepanjang tahun. Peningkatan laba akuntansi dapat mendorong investor untuk lebih tertarik dalam membeli saham perusahaan. Ketertarikan investor untuk membeli saham perusahaan akan dapat meningkatkan harga saham perusahaan dan berujung pada meningkatnya return saham perusahaan. Laba yang tinggi akan mendorong investor untuk membeli saham perusahaan yang bersangkutan karena tertarik akan laba investasi yang lebih tinggi. Ini secara langsung akan mendorong pada peningkatan harga saham dan return saham perusahaan.

Chen (2009) menyatakan bahwa arus kas operasi lebih persisten jika dibandingkan dengan akrual (selisih antara laba dan arus kas operasi). Perusahaan yang memiliki akrual operasi lebih tinggi dalam labanya akan memiliki rata-rata return yang lebih rendah jika dibandingkan dengan perusahaan dengan akrual operasi yang rendah. Hal ini memunculkan dugaan bahwa keunikan laba perusahaan belum tentu direspon secara positif oleh pasar. Pasar modal bisa bereaksi negatif terhadap peningkatan laba perusahaan jika akrual dalam laba tinggi. Menurut Laksi dan Ratnadi (2005), laba akuntansi berpengaruh signifikan terhadap return saham karena laba atau keuntungan yang diperoleh dari kegiatan operasional perusahaan akan dibagikan kepada pemegang saham sebagai balas jasa telah menanamkan modalnya dalam perusahaan atau yang biasa disebut dengan dividen. Nantinya dividen tersebut merupakan salah satu komponen penyusun return saham selain capital gain. Perusahaan yang menghasilkan laba semakin besar, maka secara teoritis perusahaan itu akan mampu membagikan dividen yang semakin besar. Dengan meningkatnya dividen yang diterima oleh pemegang saham, maka return yang diterima oleh pemegang saham juga akan meningkat. 
Kreutzmann dan Pucker (2010) menyebutkan bahwa informasi akan laba akan berpengaruh terhadap return saham perusahaan. Namun hal tersebut akan sangat tergantung dengan kemampuan para analis pasar dalam menggunakan informasi akan laba dan membuat prediksi yang tepat tentang laba perusahaan di masa depan. Analisis yang tepat akan membuat investor memilih saham yang tepat yang dapat mendatangkan lebih banyak keuntungan di masa depan. Menurut Kreutzmann dan Pucker (2010), kemampuan perusahaan dalam menghasilkan laba menjadi informasi penting bagi pasar saham. Laba yang meningkat akan direspon secara positif oleh pasar.

Hilal (2009) menyatakan bahwa profitabilitas berdampak positif terhadap return saham perusahaan. Pengaruh profitabilitas terhadap return saham ini menunjukkan bahwa dengan peningkatan pada profitabilitas menunjukkan adanya peningkatan keahlian manajemen dalam mencetak laba yang berarti perusahaan akan memiliki prospek baik di masa depan. Hal ini akan berdampak pada naiknya harga saham perusahaan yang berdampak positif terhadap return saham. Semakin tinggi tingkat profitabilitas akan semakin tinggi pula return saham perusahaan (Hilal, 2009). Berdasarkan temuan riset dan argumentasi, maka hipotesis yang diajukan dalam penelitian ini adalah sebagai berikut.

$\mathbf{H}_{1}$ : Profitabilitas berpengaruh positif pada return saham.

\section{Hubungan Arus Kas Operasi denganReturn Saham}

Laporan laba dapat menimbulkan masalah karena manajemen sebagai pihak yang memberikan informasi tentang kinerja perusahaan dievaluasi dan dihargai berdasarkan laporan yang dibuatnya sendiri. Laba yang kurang berkualitas bisa terjadi karena dalam menjalankan bisnis perusahaan, manajemen bukan merupakan pemilik perusahaan. Pemisahan kepemilikan ini akan dapat menimbulkan konflik dalam pengendalian dan pelaksanaan pengelolaan perusahaan yang menyebabkan para manajer bertindak tidak sesuai dengan keinginan para pemilik. Konflik yang terjadi akibat pemisahan kepemilikan ini disebut dengan konflik keagenan.

Laba dalam laporan keuangan sering digunakan oleh manajemen untuk menarik calon investor dan kreditor sehingga laba tersebut sering direkayasa sedemikian rupa oleh manajemen untuk memengaruhi keputusan akhir pihak-pihak tersebut. Hal ini sesuai dengan signalling theory yang menunjukkan kecenderungan adanya informasi asimetri antara manajemen dan pihak di luar perusahaan. Oleh karena itu, kualitas laba akuntansi yang dilaporkan oleh manajemen menjadi pusat perhatian pihak eksternal perusahaan. Laba akuntansi yang berkualitas adalah laba akuntansi yang memiliki sedikit atau tidak mengandung gangguan persepsian (perceived noise)dan dapat mencerminkan kinerja keuangan perusahaan yang sesungguhnya (Wijayanti2006). Angka laba rentan akan manipulasi pihak manajemen maka menurut Daniati dan Suhairi (2006), perlu adanya informasi lain selain laba 
yang dapat digunakan sebagai dasar menilai harga saham perusahaan, salah satu informasi tersebut adalah informasi arus kas.

Laporan arus kas dapat memberikan informasi yang memungkinkan para pemakai untuk mengevaluasi perubahan dalam aktiva bersih perusahaan, struktur keuangan dan kemampuan untuk memengaruhi jumlah serta waktu arus kas dalam rangka adaptasi dengan perubahan keadaan dan peluang. Informasi arus kas berguna untuk menilai dan memungkinkan para pemakai mengembangkan model untuk menilai dan membandingkan nilai sekarang dari arus kas masa depan dari berbagai perusahaan. Informasi tersebut juga meningkatkan daya banding pelaporan kinerja operasi berbagai perusahaan karena dapat meniadakan pengaruh penggunaan perlakuan akuntansi yang berbeda terhadap transaksi dan peristiwa yang sama (PSAK No.2 par. 03).

Kusuma (2003) mengungkapkan bahwa beberapa literatur menganggap bahwa data arus kas merupakan indikator keuangan yang lebih baik dibandingkan dengan laba akuntansi karena laporan arus kas relatif lebih mudah diinterpretasikan dan relatif lebih sulit untuk dimanipulasi. Manipulasi terhadap laba akuntansi biasanya dilakukan melalui penggunaan metoda akuntansi yang berbeda untuk transaksi yang sama untuk tujuan-tujuan tertentu.

Persistensi kinerja laba dipengaruhi oleh besarnya komponen kas dan akrual dari laba. Komponen tersebut menjelaskan variasi return yang lebih besar daripada yang dijelaskan oleh laba agregrat itu sendiri dan bukti ini sesuai bahwa dekomposisi laba memberikan sejumlah informasi yang secara statistik signifikan yang akan hilang jika hanya laba saja yang dilaporkan. Informasi laporan keuangan dapat digunakan untuk menentukan harga sekuritas ekuitas. Persistensi kinerja laba dipengaruhi oleh besarnya komponen kas dan akrual dari laba. Penelitian relevansi nilai dirancang untuk menetapkan manfaat nilai-nilai akuntansi terhadap penilaian ekuitas perusahaan. Ada hubungan yang mapan antara earnings, nilai buku dan nilai ekuitas. Akrual memiliki peranan penting dalam pengukuran laba dan pelaporan keuangan.

Kandungan informasi laporan arus kas dapat diukur dengan menggunakan kekuatan hubungan antara arus kas dengan harga atau return saham. Informasi laporan arus kas akan dikatakan mempunyai makna apabila digunakan sebagai dasar dalam pengambilan keputusan oleh investor. Apabila dengan dipublikasikan laporan arus kas menyebabkan investor pasar modal bereaksi melakukan pembelian atau penjualan saham yang selanjutnya tercermin dalam harga saham, berarti laporan arus kas mempunyai kandungan informasi (Juanita 2008).

Laksmi dan Ratnadi (2005) menyebutkan laporan arus kas sebagai komponen penyusun laporan keuangan merupakan salah satu sumber informasi yang juga dapat menjadi perhatian investor. Laporan arus kas ditujukan untuk melaporkan penerimaan dan pengeluaran kas selama satu periode yang berasal dari aktivitas operasi, investasi dan pendanaan. Manfaat dari laporan arus kas adalah untuk memprediksi kegagalan, 
menaksir risiko, memprediksi pemberian pinjaman, penilaian perusahaan dan memberikan informasi tambahan pada pasar modal.

Daniati dan Suhairi (2006) menyebutkan bahwa aktivitas operasi adalah aktivitas penghasil utama pendapatan perusahaan (principal revenue activities) dan aktivitas lain yang bukan merupakan aktivitas investasi dan pendanaan. Pada umumnya aktivitas operasi berasal dari transaksi dan peristiwa lain yang memengaruhi penetapan laba atau rugi bersih. Arus kas operasi merupakan indikator yang menentukan apakah dari operasi perusahaan dapat menghasilkan kas yang cukup untuk melunasi pinjaman, memelihara kemampuan operasi perusahaan, membayar dividen dan melakukan investasi baru tanpa mengandalkan pada sumber pendanaan dari luar (Daniati dan Suhairi 2006).

Munte (2009) menyebutkan bahwa informasi arus kas perusahaan akan berguna untuk menentukan jumlah waktu dan kepastian arus kas masa depan perusahaan dan meneliti kecermatan taksiran arus kas masa depan. Informasi yang terdapat dalam arus kas akan tercermin dalam perilaku investor yang terlihat dari return saham perusahaan. Data dari informasi arus kas akan diuji sebagai informasi penting untuk investor untuk mengambil keputusan. Informasi arus kas diharapkan dapat menambah ketepatan investor dalam melakukan keputusan investasinya.

Huang (2009) menemukan bahwa perubahan arus kas operasi perusahaan berpengaruh terhadap return saham perusahaan. Menurut Hilal (2009), arus kas merupakan salah satu indikator nilai pasar perusahaan. Artinya perusahaan yang mempunyai arus kas yang tinggi berarti mempunyai nilai pasar yang tinggi. Nilai pasar yang tinggi ini akan mendorong investor untuk tertarik berinvestasi pada saham perusahaan itu. Tentu saja ini akan meningkatkan harga saham perusahaan dan pada akhirnya berimbas pada meningkatnya return perusahaan. Dengan demikian dapat dikatakan bahwa peningkatan arus kas akan mendorong peningkatan pada return saham. Demikian pula sebaliknya, penurunan dalam arus kas dapat mendorong penurunan pada return saham (Hilal 2009).

Kandungan informasi arus kas dan laba akrual dengan return saham tersebut menunjukkan adanya kandungan informasi pada data arus kas. Laporan arus kas harus disajikan dengan memerinci komponen-komponen arus kas dari aktivitasaktivitas operasi, investasi dan pendanaan. Pembedaan komponen-komponen arus kas ini penting karena tiap-tiap komponen tersebut dianggap mempunyai pengaruh yang berbeda-beda terhadap return sekuritas.

Sifat kandungan informasi komponen akrualdan komponen arus kas tersebut terefleksi dalam harga saham. Hasil menunjukkan bahwa kinerja labayang teratribut pada komponen akrualmenggambarkan persistensi yang lebih rendah daripada kinerja labayang teratribut pada komponen arus kas. Harga saham bereaksi jika investor percaya pada laba, gagal membedakan antara komponen akrual dan komponen arus kas. Akibatnya, perusahaan-perusahaan yang level akrualnya relatif tinggi mengalami abnormal return di sekitar pengumuman laba. 
Fan dan Muhamad (2008) menjelaskan bahwa penelitian tentang pengaruh arus dalam kaitannya dengan pengungkapan laba memberikan hasil yang tidak konklusif. Beberapa riset sebelumnya menunjukkan bahwa di USA informasi akan laba akan memengaruhi harga saham perusahaan dimana investor akan mempertimbangkan juga pengungkapan tentang arus kas perusahaan. Informasi akan arus kas perusahaan lebih direaksi oleh pasar saham jika dibandingkan dengan informasi akan laba.

Campbell et al. (2009) mengungkapkan bahwa hubungan antara arus kas dan return perusahaan menjadi perhatian dari beberapa penelitian positif di USA. Informasi akan arus kas perusahaan memberikan gambaran kepada investor tentang kondisi masa depan perusahaan. Perusahaan dengan kondisi kas yang baik memiliki kesempatan pertumbuhan yang lebih baik, meskipun laba akrual kecil namun apabila informasi akan arus kas perusahaan baik maka pasar akan memberikan reaksi yang positif.

Berdasarkan pada beberapa penelitian di atas, peneliti berpendapat bahwa laba tidak dijadikan indikator yang tunggal dalam menentukan nilai perusahaan yang terrefleksikan dalam harga saham. Laba rentan akan tindakan manajemen laba sehingga investor juga memperhatikan laporan arus kas perusahaan tertutama arus kas operasi untuk menilai kinerja perusahaan. Pasar akan bereaksi positif jika perusahaan melaporkan profitabilitas yang baik yang juga diikuti dengan informasi arus kas yang baik. Berdasarkan hal tersebut maka peneliti berpendapat arus kas operasi akan menjadi variabel yang memperkuat hubungan antara informasi akan laba dan return saham. Berdasarkan temuan riset sebelumnya di atas, maka hipotesis dua dapat dinyatakan sebagai berikut.

$\mathbf{H}_{2}$ : Arus kas operasi memoderasi hubungan antara profitabilitas dan return saham.

\section{Hubungan Ukuran Perusahaan denganReturn Saham}

Faktor ukuran perusahaan yang berpengaruh terhadap besar kecilnya perusahaan merupakan faktor penting dalam pembentukan laba perusahaan. Perusahaan yang besar telah dianggap mencapai tahap kedewasaan dimana perusahaan tersebut akan relatif stabil dan dapat menghasilkan laba jika dibandingkan dengan perusahaan kecil. Perusahaan besar lebih memiliki kepastian usaha sehingga ketepatan prediksi tentang laba perusahaan di masa depan lebih tinggi. Kepastian ini dapat menjadi dasar investor dalam mengambil keputusan sehingga ukuran perusahaan dapat berpengaruh positif terhadap return saham (Sembiring 2008).

Daniati dan Suhairi (2006) menyatakan salah satu tolak ukur yang menunjukkan besar kecilnya perusahaan adalah ukuran aktiva dari perusahaan tersebut. Perusahaan yang memiliki total aktiva besar menunjukkan bahwa perusahaan tersebut telah mencapai tahap kedewasaan dimana dalam tahap ini arus kas perusahaan sudah positif dan dianggap memiliki prospek yang baik dalam jangka 
waktu yang relatif lama, selain itu juga mencerminkan bahwa perusahaan relatif lebih stabil dan lebih mampu menghasilkan laba dibanding perusahaan dengan total aset yang kecil.

Saham dari perusahaan kecil lebih jarang diperdagangkan jika dibandingkan dengan saham perusahaan besar. Hal ini disebabkan karena investor menilai perusahaan besar memiliki tingkat stabilitas operasi yang tinggi. Cui dan Wu (2007) menyebutkan bahwa ukuran perusahaan merupakan sebuah anomali bagi return saham. Perusahaan kecil memiliki lingkup bisnis yang kecil sehingga para investor menganggap perusahaan kecil kehilangan nilai pasar yang disebabkan oleh kinerja yang buruk di masa lalu. Menurut Cui dan Wu (2007), faktor lain yang berpengaruh terhadap return saham adalah masalah likuiditas. Perusahaan yang besar memiliki tingkat likuiditas yang tinggi yang disebabkan karena sahamnya sering diperdagangkan. Hal ini akan membuat investor bisa mengompromikan return yang dinginkan.

Munte (2009) menyebutkan bahwa perusahaan dengan ukuran besar diasumsikan telah ada pada fase kedewasaan sehingga perusahaan diharapkan memiliki aktivitas operasional yang stabil, menghasilkan profit yang lebih besar dan tidak rentan terhadap kebangkrutan. Munte (2009) menduga bahwa terdapat pengaruh positif antara ukuran perusahaan terhadap return saham. Investor yang suka menghindari risiko akan memiliki kecenderungan untuk berinvestasi pada perusahaan yang besar dari pada perusahaan yang kecil.

Bagnoli et al. (2010) berpendapat jika analisis dihadapkan pada pilihan rekomendasi dari dua saham yang sama-sama profitabel, maka analis akan memasukan faktor lain sebelum memberikan rekomendasinya. Adanya faktor lain inilah yang membuat peneliti menduga bahwa ada pengaruh aspek selain laba yang dapat berpengaruh terhadap return saham. Salah satu faktor tersebut adalah ukuran perusahaan. Ukuran perusahaan akan memengaruhi keputusan analisis jika dihadapkan pada dua saham dengan profitabilitas yang sama baiknya.

Berdasar pada beberapa penelitian di atas, bahwa ukuran perusahaan akan direaksi secara positif oleh pasar karena dianggap prospek pertumbuhan yang baik di masa depan. Informasi akan laba akan direaksi semakin positif oleh pasar jika aktiva perusahaan juga tumbuh. Hal ini menunjukkan perusahaan melakukan reinvestasi yang memberikan prospek keuntungan bagi perusahaan di masa depan, sehingga ukuran perusahaan memperkuat hubungan antara informasi akan laba dan return saham perusahaan.Berdasar pembahasan di atas, maka hipotesis yang diajukan dalam penelitian ini adalah sebagai berikut.

H3: Ukuran perusahaan memoderasi hubungan antara profitabilitas dan return saham.

\section{METODA PENELITIAN}




\section{Sampel dan Data}

Populasi dalam penelitian ini adalah perusahaan manufaktur yang terdaftar pada Bursa Efek Indonesia dari tahun 2006 sampai dengan 2008. Teknik pengambilan sampel dalam penelitian ini adalah dengan menggunakan purposive sampling, artinya bahwa populasi yang akan dijadikan sampel dalam penelitian ini adalah populasi yang memenuhi kriteria tertentu sesuai dengan yang dikehendaki peneliti.

Beberapa kriteria yang ditetapkan untuk memperoleh sampel adalah sebagai berikut: Perusahaan manufaktur yang telah terdaftar pada BEI sejak tahun 2006 sampai dengan 2008,perusahaan manufaktur telah menerbitkan laporan keuangan dalam mata uang Rupiah dan tidak de-listing selama 2006-2008,perusahaan sampel menerbitkan laporan tahunan yang diaudit yang berakhir pada tanggal 31 Desember. Ini bertujuan untuk menghindari adanya pengaruh waktu parsial dalam pengukuran,sampel adalah perusahaan yang memenuhi seluruh kualifikasi di atas dan data dapat diperoleh dari sumber data yang telah ditentukan.

Data yang digunakan dalam penelitian ini adalah data sekunder yaitu data yang diperoleh secara tidak langsung dari objek penelitian yang bersumber dari data base BEI yangtersedia secara online pada situs $h t t p: / / w w w . i d x . c o . i d$ dan dari laporan keuangan auditan tahun 2006-2008. Berdasarkan kriteria yang telah diperoleh sampel dengan rincian sebagai berikut:

Tabel 1

Hasil Pengambilan Sampel

\begin{tabular}{lc}
\hline \multicolumn{1}{c}{ Kriteria Sampel } & Jumlah \\
\hline Perusahaan sampel tahun 2006 & 107 \\
Perusahaan sampel tahun 2007 & 107 \\
Perusahaan sampel tahun 2008 & 107 \\
Jumlah observasi selama tahun 2006-2008 & 321 \\
Data outlier & 120 \\
Jumlah sampel & 201 \\
\hline
\end{tabular}

Dari tabel di atas diketahui bahwa jumlah sampel tahun 2006 sampai dengan tahun 2008 sebanyak 321 perusahaan jenis industri manufaktur. Peneliti melakukan uji outlier dengan tujuan memperoleh data dengan distribusi normal. Uji outlier dilakukan dengan pendekatan nilai Z. Data dengan nilai $\mathrm{Z}$ mendekati tiga dianggap outlier (Ghozali 2005), sehingga harus dikeluarkan dari analisis. Hasil uji outlier menunjukkan terdapat 120 data yang outlier. Jumlah sampel yang digunakan dalam penelitian ini sebanyak 201 observasi selama tahun 2006-2008.

\section{Variabel dan Pengukuran Variabel}


Variabel dependen dari penelitian ini adalah return saham. Return saham adalah income yang diperoleh pemegang saham sebagai hasil investasi di perusahaan tertentu. Return saham diproksikan dengan RET. Return saham diukur dengan:

$$
\mathrm{RET}=\frac{\mathrm{P}_{\mathrm{t}}-\mathrm{P}_{\mathrm{t}-1}}{\mathrm{P}_{\mathrm{t}-1}}
$$

\section{Keterangan:}

RET = Return saham pada periode $\mathrm{t}$,

$\mathrm{Pt} \quad=$ Harga saham pada periode $\mathrm{t}$ dan

$\mathrm{Pt}-1=$ Harga saham pada periode $\mathrm{t}-1$

Variabel independen dalam penelitian ini adalah profitabilitas. Profitabilitas dapat didefinisikan sebagai kemampuan perusahaan dalam menghasilkan laba. Profitabilitas diproksikan dengan profitabilitas (ROA). Profitabilitas diukur dengan:

$$
\mathrm{ROA}=\frac{\text { Laba bersih setelah pajak }}{\text { Total aset }}
$$

\section{Keterangan:}

ROA

Laba bersih setelah pajak Total Aset
$=($ Return on Assets $)$ adalah proksi dari profitabilitas.

$=$ penghasilan bersih yang diperoleh perusahaan dari usaha pokok dan di luar usaha pokok selama 1 periode setelah dikurangi pajak penghasilan.

$=$ jumlah dari aset lancar dan aset tetap yang merupakan harta perusahaan secara keseluruhan.

Variabel moderasi dalam penelitian ini adalah arus kas operasi dan ukuran perusahaan. Arus kas operasi menunjukkan aliran kas masuk atau aliran kas keluar dalam satu periode akuntansi. Arus kas operasi diproksikan dengan CFO. Arus kas operasi diukur dengan:

$$
\mathrm{CFO}=\text { Cash in flow }- \text { Cash out flow }
$$

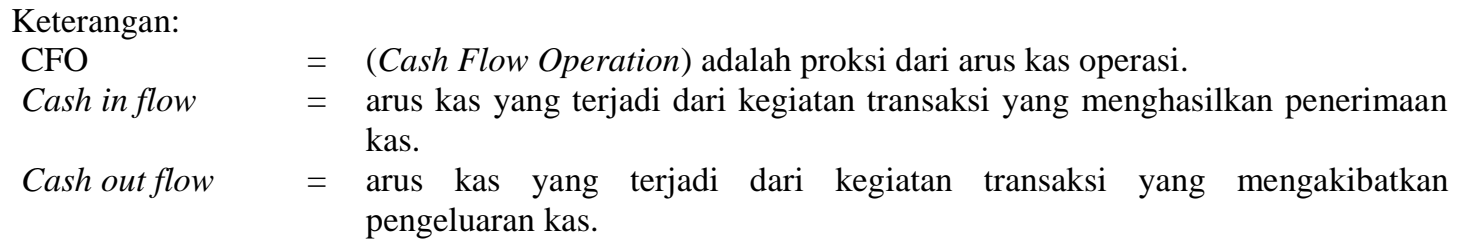
kas.

Cash outflow = arus kas yang terjadi dari kegiatan transaksi yang mengakibatkan pengeluaran kas.

Ukuran perusahaan dapat didefinisikan besarnya perusahaan menurut jumlah total aktiva yang dimiliki. Ukuran perusahaan diproksikan dengan LogNFS. Ukuran perusahaan diukur dengan:

Firm Size $=$ Ln (Total Aset $)$

Keterangan: 
Firm Size $\quad=$ ukuran perusahaan

Ln $\quad=$ logaritma yang berbasis e $(e=2,718281828459)$

\section{Model Estimasi}

Secara sistematis model yang dikembangkan dalam penelitian ini adalah sebagai berikut.

$$
\begin{aligned}
& \mathrm{RET}=\alpha+\mathrm{b}_{1} \mathrm{ROA}+\mathrm{b}_{2} \mathrm{CFO}+\mathrm{b} 3 \operatorname{LogNFS}+\mathrm{e} \\
& \mathrm{RET}=\alpha+b_{1} \mathrm{ROA}+\mathrm{b}_{2} \mathrm{CFO}+\mathrm{b} 3 \operatorname{LogNFS}+\mathrm{b} 4 \mathrm{ROA} * \mathrm{CFO}+\mathrm{b} 5 \mathrm{ROA} * \operatorname{LogNFS}+\mathrm{e}
\end{aligned}
$$

\section{Keterangan:}

$\begin{array}{ll}\text { RET } & =\text { return saham, } \\ \alpha & =\text { konstanta, } \\ \mathrm{b}_{1}-\mathrm{b}_{5}, & =\text { koefisien regresi masing-masing variabel, } \\ \mathrm{ROA} & =\text { Return on Assets proksi dari profitabilitas, } \\ \text { CFO } & =\text { Cash Flow Operation proksi dari arus kas operasi, } \\ \text { LogNFS } & =\text { Log natural total aktiva proksi dari ukuran perusahaan dan } \\ \mathrm{e} & =\text { error term. }\end{array}$

\section{Pengujian Hipotesis}

Pengujian hipotesis dilaksanakan sebagai berikut: pertama menggunakan koefisien determinasi. Koefisien determinasi adalah nilai yang menunjukkan seberapa besar variabel independen dapat menjelaskan variabel dependennya. Nilai koefisien determinasi $\left(\mathrm{R}^{2}\right)$ dilihat pada hasil pengujian regresi linier berganda untuk variabel independen terhadap variabel dependennya. Koefisien determinasi dapatdilihat dari nilai adjusted $R^{2}$, menggunakan nilai $\mathrm{F}$, nilai $\mathrm{F}$ regersibertujuan untuk mengetahui pengaruh bersama-sama terhadap vaiabel dependen. Nilai F menunjukkan pengaruh secara bersama-sama berpengaruh terhadap dependen jika nilai p lebih kecil dari0,05 (Ghozali 2005),menggunakan nilai t, nilai t bertujuan menguji pengaruh variabel independen terhadap variabel dependen. Jika nilai $\mathrm{p}$ di bawah 0,05 maka variabel independen dikatakan berpengaruh signifikan terhadap variabel dependen (Ghozali 2005). Keseluruhan analisis dan pengujian statistik dalam penelitian ini akandilakukan dengan menggunakan alat bantu perangkat lunak SPSS 15 for window.

\section{HASIL PENELITIAN DAN PEMBAHASAN Pengujian Statistik Diskriptif}

Dilakukan pengujian statistik deskriptif untuk jumlah sampel dalam penelitian ini sebanyak 201 observasi selama tahun 2006-2008, pengujian ini meliputi pengujian terhadap nilai minimum, nilai maksimum, rata-rata dan standar deviasi. Berikut hasil uji statistik deskriptif dari masing-masing variabel penelitian:

Tabel 2

Statistik Deskriptif

\begin{tabular}{lllll}
\hline $\mathrm{N}$ & Minimum & Maksimum & Rata-rata & Standar Deviasi \\
\hline
\end{tabular}




\begin{tabular}{lccccc}
\hline RET & 201 & $-1,00$ & 2,14 & $-0,01$ & 0,06 \\
CFO & 201 & $-0,04$ & 0,47 & 0,06 & 0,12 \\
LogNFS & 201 & 22,74 & 30,81 & 27,19 & 1,43 \\
ROA & 201 & $-0,04$ & 0,39 & 0,02 & 0,10 \\
\hline
\end{tabular}

Keterangan:

ROA $=$ profitabilitas,

RET = return saham,

$\mathrm{CFO}=$ arus kas operasi dan

LogNFS $=$ ukuran perusahaan.

Tabel di atas menunjukkan bahwa variabel return saham memiliki nilai minimum sebesar $-1,00$ dengan nilai maksimum 2,14. Nilai rata-rata return saham sebesar -0,01 dengan standar deviasi sebesar 0,06. Variabel profitabilitas perusahaan memiliki nilai minimum sebesar $-0,04$ dengan nilai maksimum 0,47 . Nilai rata-rata profitabilitas perusahaan sebesar 0,01 dengan standar deviasi sebesar 0,06. Variabel arus kas operasi perusahaan memiliki nilai minimum sebesar -0,04 dengan nilai maksimum 0,47. Nilai rata-rata arus kas operasi sebesar 0,06 dengan standar deviasi sebesar 0,12. Variabel ukuran perusahaan memiliki nilai minimum sebesar 22,47 dengan nilai maksimum 30,81. Nilai rata-rata ukuran perusahaan sebesar 27,19 dengan standar deviasi sebesar 1,43.

\section{Uji Asumsi Klasik}

Uji normalitas data bertujuan mengetahui apakah data yang digunakan dalam penelitian telah terdistribusi dengan normal. Ghozali (2005) menyatakan bahwa pendekatan uji One-Sample Kolmogorov-Smirnov dapat digunakan untuk menguji normalitas data. Hasil uji normalitas tersaji pada tabel berikut ini.

Hasil uji normalitas data dengan One-Sample KolmogorovSmirnovmenunjukkan bahwa nilai p sebesar 0,196, nilai tersebut di atas 0,05 sehingga dapat disimpulkan bahwa data dalam penelitian ini telah terdistribusi dengan normal.

Tabel 3

Uji Normalitas Data

\begin{tabular}{lcccl}
\hline $\mathrm{N}$ & $\begin{array}{c}\text { Kolmogorov- } \\
\text { Smirnov } Z\end{array}$ & $\begin{array}{c}\text { Asymp. } \\
\text { Sig. (2-tailed) }\end{array}$ & Kriteria & Keterangan \\
\hline 201 & 1,078 & 0,196 & $>0,05$ & Normal \\
\hline
\end{tabular}

Multikolinieritas merupakan pengujian yang digunakan untuk mengetahui korelasi antar variabel independen. Model regresi yang baik mengharapkan korelasi yang rendah antar variabel independen. Keberadaan multikolinieritas dideteksi dengan Varians Inflating Factor (VIF) dan Tolerance (Ghozali 2005). Hasil uji multikolinieritas tersaji pada Tabel 4 berikut ini.

Tabel 4

Uji Multikolinieritas 


\begin{tabular}{cccl}
\hline Variabel & Tolerance & VIF & Keterangan \\
\hline ROA & 0,823 & 1,202 & Tidak terdapat multikolinieritas \\
CFO & 0,827 & 1,209 & Tidak terdapat multikolinieritas \\
LogNFS & 0,992 & 1,008 & Tidak terdapat multikolinieritas \\
\hline
\end{tabular}

Hasil uji multikolinieritas menunjukkan bahwa semua nilai tolerance di atas 10 persen dan semua nilai VIF di bawah 10, sehingga dengan mengacu pada Ghozali (2005) dapat disimpulkan bahwa dalam model tidak terjadi multikolinieritas.

Uji autokorelasi adalah sebuah pengujian yang bertujuan untuk menguji apakah di dalam model regresi linier ada korelasi antara kesalahan pengganggu pada periode $\mathrm{t}$ dengan kesalahan pengganggu pada periode t-1. Cara untuk mendeteksi autokorelasi adalah menggunakan kriteria yang diungkapkan Santoso (2000) yang mengatakan bila nilai $\mathrm{D}-\mathrm{W}$ hitung mendekati +2 maka dalam model regresi tidak terjadi autokorelasi. Hasil uji autokorelasi dengan Durbin Watson dapat dilihat pada tabel berikut ini.

Tabel 5

Uji Autokorelasi

\begin{tabular}{lll}
\hline D-W Hitung & Kriteria & Keterangan \\
\hline 1,730 & Mendekati +2 & Tidak terdapat autokorelasi \\
\hline
\end{tabular}

Hasil uji autokorelasi dengan menggunakan uji Durbin Watson menunjukkan nilai D-W hitung sebesar 1,730 . Hasil tersebut mendekati nilai +2 sehingga dapat disimpulkan bahwa dalam model regresi tidak terjadi autokorelasi.

Model regresi yang baik adalah yang homokedastisitas atau tidak heteroskedastisitas (Ghozali2005). Uji heteroskedastisitas dalam penelitian ini diuji dengan Scaterplots (Ghozali 2005). Hasil uji heteroskedastisitas dapat dilihat pada gambar berikut ini:

Scatterplot

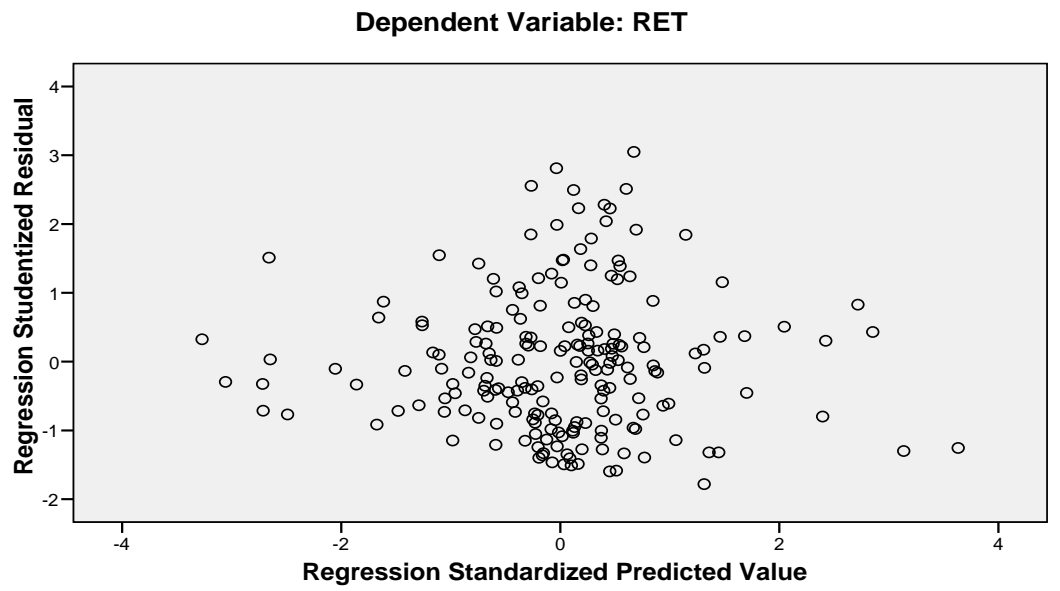




\section{Gambar 1 \\ Scatterplot}

Hasil uji heteroskedastisitas menunjukkan bahwa titik-titik tersebar di atas dan di bawah angka nol sehingga dapat disimpulkan bahwa dalam model regresi tidak terjadi heteroskedastisitas.

\section{Uji Hipotesis: Regresi Persamaan 1}

Hasil uji koefisien determinasi untuk regresi linier berganda persamaan 1 yang digunakan dalam penelitian ini tersaji pada Tabel 6.

Tabel 6

Koefisien Determinasi

\begin{tabular}{lccc}
\hline $\mathrm{R}$ & R Square & Adjusted R square & $\begin{array}{c}\text { Standard error of } \\
\text { the estimate }\end{array}$ \\
\hline 0,227 & 0,077 & 0,063 & 0,668 \\
\hline
\end{tabular}

Dari tabel di atas diketahui bahwa koefisien determinasi menunjukkan nilai $R$ square sebesar 0,063 . Hal ini berarti 6,3 persen variasi perubahan return saham perusahaan dapat dijelaskan oleh profitabilitas, arus kas operasi dan ukuran perusahaan, sisanya 93,7 persen perubahan return saham dipengaruhi faktor lain di luar model penelitian.Hasil uji nilai F statistik tersaji pada Tabel7.

Tabel 7

Nilai F Regresi

\begin{tabular}{lccccc}
\hline Model & Sum of Squares & df & Mean Square & F & Nilai $\mathrm{p}$ \\
\hline Regression & 7,31 & 3 & 2,439 & 5,468 & 0,001 \\
Residual & 87,87 & 197 & 0,446 & & \\
Total & 95,19 & 200 & & & \\
\hline
\end{tabular}

Nilai F regresi bertujuan untuk menguji pengaruh variabel independen secara simultan terhadap variabel dependen (Ghozali 2005). Hasil uji nilai F menunjukkan nilai $F$ sebesar 5,468 dengan nilai p sebesar 0,001, sehingga dapat disimpulkan bahwa profitabilitas, arus kas operasi dan ukuran perusahaan berpengaruh secara simultan terhadap return saham. Hasil uji nilai t statistik tersaji pada Tabel8 berikut:

Tabel8

Nilai t Regresi 


\begin{tabular}{lccccc}
\hline Variabel & $\begin{array}{c}\text { Koefisien } \\
\text { Regresi }\end{array}$ & $\begin{array}{c}\text { Standar } \\
\text { Error }\end{array}$ & $\begin{array}{c}\text { Koefisien } \\
\text { Korelasi }\end{array}$ & t hitung & Nilai p \\
\hline Kostanta & 1,916 & 0,899 & & 2,131 & 0,034 \\
ROA & 1,691 & 0,501 & 0,254 & 3,378 & 0,001 \\
CFO & $-0,284$ & 0,423 & $-0,051$ & $-0,671$ & 0,503 \\
LogNFS & $-0,072$ & 0,033 & $-0,150$ & $-2,178$ & 0,031 \\
\hline
\end{tabular}

Hasil uji regresi menunjukkan koefisien regresi sebesar sebesar 1,691 dengan nilai $\mathrm{p}$ sebesar 0,001.Uji regresi memberikan hasil yang signifikan, sehingga dapat disimpulkan bahwa profitabilitas berpengaruh terhadap return saham.

\section{Uji Hipotesis: Regresi Persamaan 2}

Regresi persamaan 2 digunakan untuk menguji peran variabel arus kas operasi dan ukuran perusahaan sebagai variabel moderasi. Hasil uji koefisien determinasi untuk regresi linier berganda persamaan 2 tersaji pada tabel berikut ini.

Tabel 9

Determinasi Model Moderasi

\begin{tabular}{llll}
\hline $\mathrm{R}$ & $\mathrm{R}$ Square & Adjusted R square & $\begin{array}{l}\text { Standard error of } \\
\text { the estimate }\end{array}$ \\
\hline 0,280 & 0,079 & 0,055 & 0,670 \\
\hline
\end{tabular}

Dari tabel di atas diketahui bahwa koefisien determinasi menunjukkan nilai $R$ square sebesar 0,055. Hal ini berarti 5,5 persen variasi perubahan return saham perusahaan dapat dijelaskan oleh profitabilitas, arus kas operasi dan ukuran perusahaan, interaksi antara arus kas operasi dan profitabilitas serta interaksi antara ukuran perusahaan dan profitabilitas. Nilai koefisien determinasi turun dari regresi persamaan 1 sebesar 6,3 persen sehingga kemungkinan arus kas operasi dan ukuran perusahaan bukan merupakan variabel moderasi.Hasil uji nilai $\mathrm{F}$ statistik tersaji pada tabel berikut ini.

Tabel 10

Nilai F Regresi Model Moderasi

\begin{tabular}{lccccc}
\hline Model & Sum of Squares & df & Mean Square & F & Nilai p \\
\hline Regression & 7,488 & 5 & 1,498 & 3,330 & 0,007 \\
Residual & 87,704 & 195 & 0,450 & & \\
Total & 95,192 & 200 & & & \\
\hline
\end{tabular}


Nilai F regresi bertujuan untuk menguji pengaruh variabel independen secara simultan terhadap variabel dependen (Ghozali 2005). Hasil uji nilai $F$ menunjukkan nilai $F$ sebesar 3,330 dengan nilai p sebesar 0,007, sehingga dapat disimpulkan bahwa profitabilitas, arus kas operasi, ukuran perusahaan, interaksi antara arus kas operasi dan profitabilitas serta interaksi antara ukuran perusahaan dan profitabilitas berpengaruh secara simultan terhadap return saham. 
Hasil uji nilai t statistik tersaji pada tabel berikut ini:

Tabel 11

Nilai t Regresi Model Moderasi

\begin{tabular}{lccccc}
\hline Variabel & $\begin{array}{c}\text { Koefisien } \\
\text { Regresi }\end{array}$ & $\begin{array}{c}\text { Standar } \\
\text { Error }\end{array}$ & $\begin{array}{c}\text { Koefisien } \\
\text { Korelasi }\end{array}$ & thitung & Nilai p \\
\hline Kostanta & 2,089 & 0,951 & & 2,196 & 0,029 \\
ROA & $-2,605$ & 7,543 & $-0,391$ & $-0,345$ & 0,730 \\
CFO & $-0,237$ & 0,459 & $-0,042$ & $-0,516$ & 0,606 \\
LogNFS & $-0,078$ & 0,035 & $-0,163$ & $-2,239$ & 0,026 \\
ROA*CFO & $-0,936$ & 2,629 & $-0,031$ & $-0,356$ & 0,722 \\
ROA* LogNFS & 0,162 & 0,280 & 0,658 & 0,577 & 0,565 \\
\hline
\end{tabular}

Hasil uji regresi menunjukkan koefisien regresi sebesar -0,936 dengan nilai $p$ sebesar 0,722 . Uji regresi dengan moderasi memberikan hasil yang tidak signifikan, sehingga dapat disimpulkan bahwa arus kas operasi bukan merupakan variabel moderasi dalam pengaruh profitabilitas terhadap return saham.

Hasil uji regresi menunjukkan koefisien regresi sebesar sebesar 0,162 dengan nilai p sebesar 0,566. Uji regresi dengan moderasi memberikan hasil yang tidak signifikan, sehingga dapat disimpulkan bahwa ukuran perusahaan bukan merupakan variabel moderasi dalam pengaruh profitabilitas terhadap return saham.

\section{PEMBAHASAN}

Berdasarkan pengujian hipotesis yang telah dilakukan, diperoleh bahwa return saham yang dilihat menggunakan variabel arus kas operasi dan ukuran perusahaan tidak memiliki pengaruh yang signifikan terhadap perusahaan. Hanya profitabilitas yang mampu memiliki pengaruh positif signifikan terhadap return saham. Penggunaan arus kas operasi dan ukuran perusahaan sebagai pemoderasi menunjukkan bahwa arus kas operasi tidak mampu secara signifikan memoderasi pengaruh profitabilitas terhadap return saham.

Hipotesis 1 dalam penelitian ini bertujuan untuk menguji pengaruh profitabilitas terhadap return saham. Hasil uji regresi menunjukkan koefisien regresi sebesar sebesar 1,691 dengan nilai p sebesar 0,001.Uji regresi memberikan hasil yang signifikan, sehingga dapat disimpulkan bahwa profitabilitas berpengaruh terhadap return saham. Hipotesis 1 didukung. Koefisien regresi memberikan nilai positif, yang berarti semakin tinggi profitabilitas perusahaan akan semakin tinggi pula return saham perusahaan. Hasil penelitian ini mendukung hasil penelitian Hilal (2009) yang menyatakan bahwa profitabilitas berdampak positif terhadap return saham perusahaan. Laksi dan Ratnadi (2005) menjelaskan bahwa profitabilitas adalah kemampuan perusahaan dalam menghasilkan laba. Semakin baik profitabilitas akan semakin tinggi penghargaan pasar terhadap saham perusahaan. Peningkatan harga saham perusahaan akan meningkatkan return saham perusahaan. 
Hasil pengujian terdapat variabel arus kas operasi menunjukkan nilai koefisien regersi sebesar $-0,084$ dengan nilai $p$ sebesar 0,503. Sedangkan untuk variabel ukuran perusahaan di peroleh koefisien sebesar -0,072 dengan nilai p 0,031. Pengujian terhadap ukuran perusahaan mendukung penelitian Davis (2001). Variabel arus kas operasi tidak berpengaruh signifikan terhadap return saham dan ukuran perusahaan berpengaruh negatif terhadap return saham. Pengujian variabel arus kas operasi dan ukuran perusahaan pada regresi persamaan 1 tidak masuk dalam pengujian hipotesis.

Hipotesis 2 dalam penelitian ini bertujuan untuk menguji peran arus kas operasi sebagai variabel moderasi dalam pengaruh profitabilitas terhadap return saham. Hasil uji regresi menunjukkan koefisien regresi sebesar sebesar -0,936 dengan nilai $\mathrm{p}$ sebesar 0,722 . Uji regresi dengan moderasi memberikan hasil yang tidak signifikan, sehingga dapat disimpulkan bahwa arus kas operasi bukan merupakan variabel moderasi dalam pengaruh profitabilitas terhadap return saham. Hasil penelitian ini mendukung hasil penelitian Campbell et al. (2009) yang menyatakan bahwa arus kas operasi memperkuat pengaruh profitabilitas terhadap return saham perusahaan. Pengujian secara langsung arus kas operasi terhadap return saham memberikan hasil yang tidak signifikan, sedangkan pengujian sebagai variabel moderasi juga memberikan signifikan. Namun demikian hal tersebut bisa dijelaskan dengan hasil penelitian Fan dan Muhamad (2008). Menurut Fan dan Muhamad (2008), informasi akan arus kas perusahaan memberikan dampak yang signifikan dalam pengumuman laba terhadap harga saham perusahaan pada window yang singkat yaitu sekitar tiga hari setelah pengumuman. Pada jangka panjang seperti dengan memakai data tahunan, informasi akan arus kas perusahaan tidak berdampak signifikan pada harga saham perusahaan. Investor akan lebih nyaman menggunakan data informasi akan laba untuk menilai harga saham perusahaan.

Hipotesis 3 dalam penelitian ini bertujuan untuk menguji peran ukuran perusahaan sebagai variabel moderasi dalam pengaruh profitabilitas terhadap return saham. Hasil uji regresi menunjukkan koefisien regresi sebesar sebesar 0,162 dengan nilai $\mathrm{p}$ sebesar 0,566. Uji regresi dengan moderasi memberikan hasil yang tidak signifikan, sehingga dapat disimpulkan bahwa ukuran perusahaan bukan merupakan variabel moderasi dalam pengaruh profitabilitas terhadap return saham. Hipotesis 3 tidak didukung. Hasil penelitian ini mendukung hasil penelitian Bagnoli (2010) yang menyatakan bahwa ukuran perusahaan memperkuat pengaruh profitabilitas terhadap return saham perusahaan. Namun demikian hasil penelitian ini mendukung hasil penelitian Davis (2001) yang menyatakan bahwa ukuran perusahaan berpengaruh negatif terhadap return saham. Perusahaan dengan ukuran yang kecil memiliki risiko yang besar dalam operasional bisnisnya sehingga perusahaan akan memberikan return yang besar untuk menarik minat para investor. 


\section{SIMPULAN, IMPLIKASI, KETERBATASAN DAN SARAN}

\section{Simpulan}

Penelitian ini bertujuan mengetahui pengaruh profitabilitas terhadap return saham dengan arus kas operasi dan ukuran perusahaan sebagai variabel moderasi pada perusahaan manufaktur yang terdaftar di Bursa Efek Indonesia.Analisis data dalam penelitian ini menggunakan dua model regresi linier berganda. Berdasar analisis dan pembahasan pada bab sebelumnya maka peneliti mengambil kesimpulan sebagai berikut:

Pertama, profitabilitas berpengaruh positif terhadap return saham. Hasil penelitian ini mendukung hasil penelitian Hilal (2009). Semakin besar profitabilitas perusahaan akan semakin besar return saham perusahaan.

Kedua, arus kas operasi tidak memoderasi hubungan antara profitabilitas dan return saham. Hasil penelitian ini tidak mendukung hasil penelitian Campbell et al. (2009), yang menyatakan bahwa arus kas operasi merupakan informasi yang akan direaksi oleh pasar sebagai salah satu pertimbangan akan profitabilitas perusahaan.

Ketiga, ukuran perusahaan tidak memoderasi hubungan antara profitabilitas danreturn saham. Hasil penelitian ini tidak mendukung hasil penelitian Bagnoli (2010), yang menyatakan bahwa ukuran perusahaan menjadi pertimbangan dalam menentukan reaksi pasar atas informasi profitabilitas perusahaan.

\section{Implikasi}

Dari hasil penelitian ini, arus kas operasi dan ukuran perusahaan tidak memoderasi hubungan antara profitabilitas dan return saham, kemungkinan pengaruhnya langsung tidak memoderasi. Dalam kenyataannya investor bereaksi setelah mengetahui kinerja keuangan perusahaan karena informasi tentang profitabilitas memiliki kandungan informasi yang digunakan untuk menilai harga saham sehingga hendaknya manajer perusahaan mempertimbangkan waktu yang tepat dalam mengumumkan laba perusahaan karena berdampak terhadap return saham perusahaan. Bagi investor, penelitian ini dapat memberikan gambaran tentang informasi yang perlu dipertimbangkan dalam menentukan harga saham perusahaan.

\section{Keterbatasan}

Seperti kebanyakan penelitian lainnya, penelitian ini memiliki keterbatasan, yaitu: pertama, penelitian ini hanya dilakukan para perusahaan manufaktur saja, belum dapat mewakili seluruh perusahaan yang terdaftar di BEI sehingga hasil penelitian ini akan dapat memberikan hasil yang berbeda jika dilakukan pada jenis perusahaan yang lain. Kedua, masih ada sejumlah variabel lain yang belum digunakan sedangkan variabel tersebut memiliki kontribusi dalam memengaruhireturn saham. Ketiga, periode penelitian ini relatif pendek karena hanya 
dilakukan pada tahun 2006-2008, sehingga penelitian dengan periode penelitian yang berbeda dimungkinkan memberikan hasil yang berbeda pula.

\section{Saran}

Berdasarkan keterbatasan pada penelitian ini, maka saran dari penelitian ini adalah: pertama, bagi perusahaan hendaknya dapat meningkatkan profitabilitas sehingga kinerja keuangan menjadi baik di mata investor dan dapat menarik investor untuk berinvestasi;kedua, bagi investor dan calon investor dalam memberikan penilaian terhadap suatu perusahaan sebaiknya juga memperhatikan faktor lain yang memengaruhireturn saham, seperti likuiditas, leverage, pertumbuhan perusahaan, keunikan perusahaan, nilai perusahaan, penghematan pajak, fluktuasi nilai tukar, kepemilikan perusahaan, kualitas laba dan keadaan pasar modal;ketiga, bagi peneliti dalam melakukan penelitian selanjutnya agar memperluas kategori perusahaan yang akan dijadikan sampel penelitian, misalnya seluruh perusahaan yang terdaftar di BEI; keempat, bagi penelitian selanjutnya disarankan untuk menambah/menguji variabel lain yang diduga berpengaruh terhadap return saham seperti likuiditas, leverage, pertumbuhan perusahaan, keunikan perusahaan, nilai perusahaan, penghematan pajak, fluktuasi nilai tukar, kepemilikan perusahaan, kualitas laba dan keadaan pasar modal.

\section{DAFTAR PUSTAKA}

Auliyah, R., dan A. Hamzah. 2006. Analisiskarakteristik perusahaan, industri dan ekonomi makro terhadap return dan beta saham syariah di Bursa Efek Jakarta. Simposium Nasional Akuntansi IX: Padang.

Bagnoli, M., M. Clament, dan S. Watts. 2010. The relative profitability of analysts' stock recommendations: What role does investor sentiment play? Availableat:http://www.ssrn.com.

Bo, J. 2009. An empirical study on information content of accounting earnings and cash flow. Journal of Modern Accounting and Auditing. Vol.5 No.7: 44-48.

Brevik, F., dan S. D'addona. 2010. Information quality and stock returns revisited. Journal of Financial and Quantitative Analysis Vol.45 No.6: 1419-1446.

Campbell, C. J., G. J. Papaioannou,dan A. Rai. 2009. Operating and stock returns following andlistings: Impact of cash flow news. Available at:http://www.ssrn.com.

Chen, K. 2009. Is cash flow really king? earnings quality and stock returns. Available at:http://www.ssrn.com.

Cui, R., dan Y. Wu. 2007. Disentangling liquidity and size effects in stock returns: evidence from China. Available at:http://www.ssrn.com.

Daniati, N., dan Suhairi. 2006. Pengaruh kandungan informasi komponen laporan arus kas, laba kotor, dan size perusahaan terhadap expected return saham. Simposium Nasional Akuntansi IX: Padang. 
Fah, C. F., dan S. Muhamad. 2008. Are cash flows relevant for stock pricing in bursa Malaysia? International Journal of Economics and Management. Vol.2. No.2: 353-367.

Febrianto, R., dan E. Widiastuty. 2005. Tiga angka laba akuntansi: Mana yang lebih bermakna bagi investor? Simposium Nasional Akuntansi VIII: Surakarta.

Ghozali, I. 2005. Aplikasi Analisis Multivariate dengan Program SPSS.Edisi Kedua. Badan Penerbit Universitas Diponegoro.

Hilal, F. 2009. Pengaruh laba akuntansi, total arus kas dan net profitmargin terhadap returnsaham perusahaan asuransi yang terdaftar pada bursa efek Indonesia. Available at:http://www.uii.ac.id.

Huang, A. G. 2009. The cross section of cashflow volatility and expected stock returns. Journal of Empirical Finance. Vol.16: 409-429.

Hartono, J. 2003. Teori Portofolio dan Analisis Investasi. Edisi III. BPFE. Yogyakarta.

Juanita, N. T. 2008. Pengaruhkandungan informasi arus kas, komponen arus kas dan laba akuntansi terhadap return saham (studi empiris pada perusahaan manufaktur di Bursa Efek Indonesia). Available at:http://www.umsi.ac.id.

Kreutzmann, D., dan O. Pucker. 2010. Projected earnings accuracy and the profitability of stock recommendations. Available at:http://www.ssrn.com.

Kusuma, P. D. I. 2003. Nilai tambah kandungan informasi laba dan arus kas operasi. Simposium Nasional Akuntansi VI: Surabaya.

Laksmi, P. A. D., dan N. M. D. Ratnadi. 2005. Dampak pemoderasian komponen arus kas terhadap hubungan laba akuntansi dengan returnsaham.Available at:http://www.udayana.ac.id.

Linda dan F. Syam. 2005. Hubungan laba akuntansi, nilai buku dan total arus kas denganmarket value: Studi akuntansi relevansi nilai. Jurnal Riset Akuntansi Indonesia. Vol.8 No.3: 286-309.

Lestari, M. 2005. Pengaruh variabel makro terhadap returndi Bursa Efek Jakarta: pendekatanbeberapa model. Simposium Nasional Akuntansi VIII: Surakarta.

Meythi. 2006. Pengaruh arus kas operasi terhadap harga saham dengan persistensi laba sebagai variabel intervening. Simposium Nasional Akuntansi IX: Padang.

Munte, M. H. M. 2009. Pengaruh faktor fundamental terhadap returnsaham perusahaan manufaktur yang terdaftar di Bursa Efek Indonesia. Tesis Universitas Sumatra Utara.

Prasetyo, J. E., dan S. Astuti. 2003. Dampak pengumuman bond rating terhadap return saham perusahaan di Bursa Efek Jakarta. Simposium Nasional Akuntansi VI: Surabaya.

Prasetyo, L. Y. 2008. Analisis pengaruh arus kas bersih operasional, gross profit margin, dan profitabilitas terhadap returnsaham perusahaan manufaktur terdaftar di BEI.Skripsi. Fakultas Ekonomi Universitas Sebelas Maret Surakarta. 
Primandoko. 2005. Pengaruh profitabilitas dan likuiditas terhadap returnsaham perusahaan yang terdaftar di Bursa Efek Jakarta.Available at:http://www.unness.ac.id.

Sembiring, S. 2008. Pengaruh ukuran perusahaan dan kebijakan pendanaan terhadap kinerja keuangan pada perusahaan properti di Bursa Efek Jakarta. Tesis. Universitas Sumatra Utara, tidak dipublikasikan.

Watson, J., dan P. Wells. 2005. The association between various earnings and cash flow measures of firm performance and stock returns: some australian evidence.Available at:http://www.ssrn.com.

Wijayanti, H. T. 2006. Analisis pengaruh perbedaan antara laba akuntansi dan laba fiskal terhadap persistensi laba, akrual dan arus kas. Simposium Nasional Akuntansi IX: Padang. 